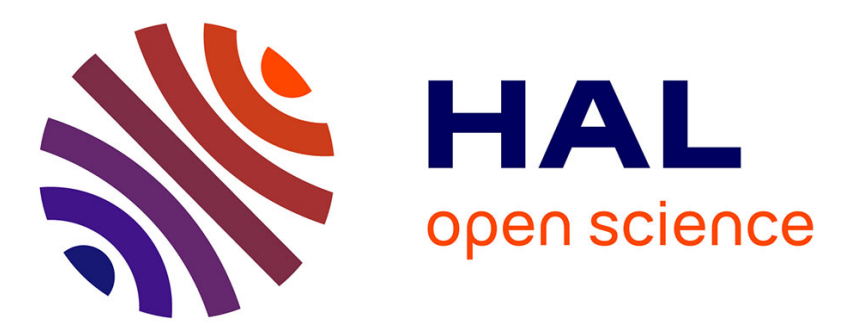

\title{
An unpublished letter of David Ricardo on the double standard of money
}

Ghislain Deleplace, Christophe Depoortère, Nicolas Rieucau

\section{To cite this version:}

Ghislain Deleplace, Christophe Depoortère, Nicolas Rieucau. An unpublished letter of David Ricardo on the double standard of money. European Journal of the History of Economic Thought, 2013, 20 (1), pp.1 - 28. 10.1080/09672567.2011.565359 . hal-01615081

\section{HAL Id: hal-01615081 \\ https://hal.science/hal-01615081}

Submitted on 11 Oct 2017

HAL is a multi-disciplinary open access archive for the deposit and dissemination of scientific research documents, whether they are published or not. The documents may come from teaching and research institutions in France or abroad, or from public or private research centers.
L'archive ouverte pluridisciplinaire HAL, est destinée au dépôt et à la diffusion de documents scientifiques de niveau recherche, publiés ou non, émanant des établissements d'enseignement et de recherche français ou étrangers, des laboratoires publics ou privés. 


\section{An unpublished letter of David Ricardo on the double standard of money}

\section{Ghislain Deleplace, Christophe Depoortère and Nicolas Rieucau}

\section{Introduction}

The letter we publish was written by David Ricardo (DR) on 19 January 1823, nearly eight months before his death. It was addressed to Pascoe Grenfell and is part of a set of five letters deposited at the British Library amongst Lord Grenville's papers. This set forms a crossed correspondence between DR, Grenfell, and Grenville on the same issue: rumours of re-establishing a double standard of money (silver along with gold), a project that the three correspondents firmly opposed.

Only one of these five letters was written by DR. None was addressed to him: DR's letter to Grenfell is obviously an answer to a letter to him from Grenfell, but this letter is not extant. Consequently, we decided to publish only DR's letter in full, the four other letters - three from Grenfell to Grenville, one from Grenville to Grenfell - being mentioned and quoted in our commentary.

In his 'Introductory Notes to the Correspondence' of DR, Piero Sraffa pointed out that 'the letters of Ricardo to Grenfell have not been found, although in 1933 searches were made, at the request of Lord Keynes, by the representatives of the two branches of the Grenfell family' (Sraffa 1952a: xxxiii). Since Sraffa's edition, which contains 15 letters from Grenfell to

\section{Address for correspondence}

All three authors: Université Paris 8-LED, UFR AES/ECO/GESTION, 2 rue de la Liberté, Saint-Denis Cedex 93526 France.

Ghislain Deleplace, e-mail: ghislain.deleplace@univ-paris8.fr

Christophe Depoortère, e-mail: christophe.depoortere@univ-paris8.fr

Nicolas Rieucau, e-mail: nicolas.rieucau@univ-paris8.fr 
DR, ${ }^{1}$ only one letter from DR to Grenfell, dated 27 August 1817, has been found: it was published in Heertje (1991). ${ }^{2}$

DR's letter we publish deserves a scholarly attention for at least three reasons. Firstly, it is a rather long letter: it contains over 650 words, with around four-fifths directly concerning the currency system, particularly the question of the double standard. Secondly, it echoes the historical context of its writing, less than two years after the resumption of cash payments at the pre-1797 parity with gold, and in the midst of an economic recession that pressed for drastic monetary changes. Thirdly, by its analytical content this letter is not only a concentrate of DR's reasoning powers: it exhibits an argument (linking the double standard of money, the seignorage on the silver coin, the issuing behaviour of the Bank of England, and the prospective fall in the value of the pound) that, to the best of our knowledge, is to be found nowhere else in DR's works.

In our view, paying a tribute to this hitherto unpublished letter required the writing of an extensive commentary, both historical and analytical. Section 2 presents the material description of the letter, including its facsimile and its transcript in extenso. Section 3 sums up its historical context. Section 4 comments on its analytical content.

\section{The letter}

\subsection{Material description}

The letter is deposited in the British Library, in the 'Series II' of the Dropmore Papers, purchased through Christie's on 19 March 1984. This

1 Thirteen letters written between 1 August and 17 October 1815 (Ricardo 1951-1973, VI), one letter dated 15 February 1818 (Ricardo 1951-1973, VII) and one letter dated 10 November 1820 (Ricardo 1951-1973, VIII). An additional one dated 8 August 1823 (the same year as the one we publish) has been discarded by Sraffa since it 'deals purely with the appointment of Ricardo as umpire' (Sraffa 1952a: xxxiii, n. 1). As for the correspondence between DR and Grenville, one letter from Grenville to DR, dated 11 January 1820, was published by Sraffa (in Ricardo 1951-1973, VIII); two letters from DR to Grenville, dated 10 January 1820 and 1 May 1822, were published in Heertje (1991). There is no reference to the issue of the double standard in any of the previously known letters between DR, Grenfell and Grenville.

2 The letters from DR found and published after the Sraffa edition are few: as far as we know, one letter to Thomas Smith (in Heertje and Weatherall 1978), one letter to Finch (in Heertje et al. 1985), one letter to Grenfell and two letters to Grenville (in Heertje 1991), and two letters to Solly (in Heertje 2007). 
series contains 374 volumes. ${ }^{3}$ DR's letter belongs to 'Part C' of this series 'Political and Financial Papers of Lord Grenville and Others: 69075$69100^{\prime 4}$ - and is more precisely kept in the unbound volume 'Add. 69082', described as follows:

Add. 69082. Dropmore Papers (Series II). Vol.XLV. Financial correspondence and papers of Grenville on particular subjects; 1803-1827. [...] 6. Correspondence of Grenville with Charles Pascoe Grenfell and Thomas Tooke, economist, concerning currency and finance; 1823-1827. Together with a letter to Grenville from David Ricardo, $1823 .^{5}$

This last statement is incorrect because the letter was not addressed by DR to Grenville but to Grenfell. The letter is numbered '102' in black pencil, by the hand of a librarian (see Figure 1). Contrary to curator's usage, and probably for reasons of space, this numbering is not in the top right of the recto of the first sheet, but at the bottom right of it, written top to bottom.

DR's letter was written full page, with a pen dipped in black ink. For reasons of space, DR had to adapt his writing at the end of his letter: the intervals between the last lines are narrowed, and a passage was added to the upside on the top right of the front of the first sheet. In view of the ductus and the colour of the ink, the writing by DR of the place and the date ('Widcombe, Bath', '19 Jan.' 1823') coincided with that passage. Therefore the author did not start his letter by writing these mentions, as might naturally be expected. Given the omnipresence of immediate crossing out, the letter seems to be a first and unique piece. The corrections as a whole cannot demonstrate that it has received a general re-reading.

The letter is in the form of a bi-sheet in- $4^{\circ}$. The thickness, height and width of this bi-sheet are respectively of $90 \mu \mathrm{m}, 190 \mathrm{~mm}$ and $228 \mathrm{~mm}$. This bi-sheet has no restoration marks. The paper type is vellum. Its colour is ecru. The watermark is 'BEVAN' (which is the surname of the

3 Series I, III and IV contain respectively 640,10 and 12 volumes. In total, the Dropmore Papers therefore include more than 1000 volumes, hence several tens of linear meters. The comprehensive and detailed catalogue of all of these volumes remains to be done. The three letters discovered by Weatherall (Heertje 1991: 519) and published in Heertje (1991) belong to the First Series: Add 59404, F. 85-6 (to Grenfell); Add 59405, F. 5-6 (first letter to Grenville) and F. 64-5 (second letter to Grenville).

4 Available at http://www.bl.uk/catalogues/manuscripts/HITS0001.ASP?VPath= arevhtml/52893.htm\&Search=Add.\%2069038\%20\&Highlight $=\mathrm{T}$.

5 Available at http://www.bl.uk/catalogues/manuscripts/HITS0001.ASP?VPath= arevhtml/52923.htm\&Search=Add.\%2069082\%20\&Highlight=T. 
papermaker $^{6}$ ), with the '1822' vintage. Besides, this bi-sheet has vertical and horizontal traces of folds. The absence of seal, of seal mark or of any postal inscription attests that DR's letter (which, being sent from outside London, could not be delivered by hand) was folded and inserted in an envelope now lost. In light of the folds of the letter, the envelope was approximately 6 $\mathrm{cm}$ high and $11 \mathrm{~cm}$ wide.

\subsection{Transcript ${ }^{7}$}

The letter is reproduced in Figures 1 and 2.

The transcript reads as follows:

Widcomb, Bath, 19 Jan. ${ }^{\mathrm{y}} 1823$

\section{My Dear Grenfell}

If I knew how to write like Lord Grenville I should express myself just as he has done on the proposed plan of again introducing the two standards. - I agree with every word that Lord Grenville has written on this subject. Since the new act for regulating the silver coinage, the execution of the plan will not be found so easy as the friends to it suppose. Formerly, when we had the two standards we were liable to the inconveniences of changing from one to the other, accordingly as one or the other of the metals became the cheapest medium whereby to discharge a debt, but whichever $[\mathbf{1} \mathbf{v}]$ metal was for the time the practical standard that metal could not be under the mint price, whilst the other was always above it. - Now, however, with a seignorage on the silver currency, nothing is to prevent the price of silver from rising to $5 / 6$ an ounce whilst it is the standard metal. Till it rises above $5 / 6$, it is will not |be| advantageous to melt the coin, and we all know that it is the melting pot only which keeps all currency in a wholesome state. In the present state of the law the public cannot take silver to the mint to be coined, a very proper regulation while silver performs only the office of counters or tokens, but once make it the standard metal, \& the mint must be open to the Bank, \& the public.

It is true that no one would carry silver to be coined when its price rose to $5 / 2$, and therefore if the mint were the only [ $2 \mathbf{r}$ ] channel by which

6 This is probably Thomas Bevan, who owned 'Bitton Mill' in County Durham (North East England) in 1812 (see Shorter 1957: 167).

7 The transcript of the letter was made ne varietur. The following symbols have been used: crossed word; |word|: added word; word [?]: uncertainty on the transcript of a word. 


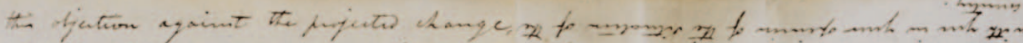

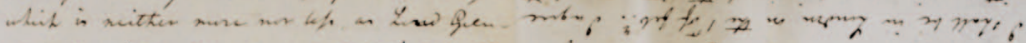

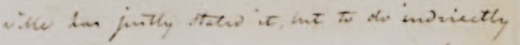

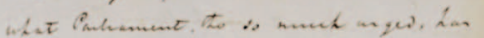

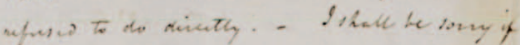

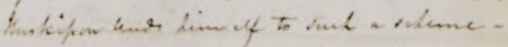

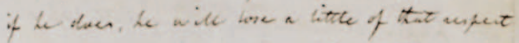

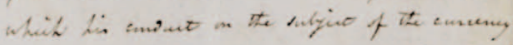
I. Litan with him to

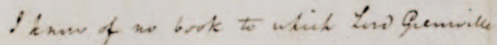

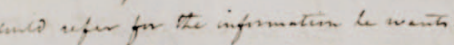

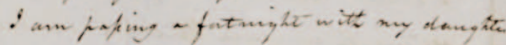

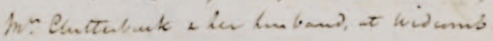

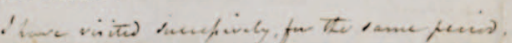

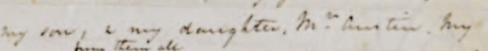

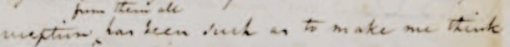

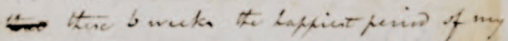
life - taw in net heen the kart alley to

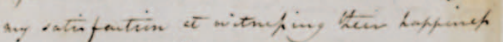
Aw2 $\longrightarrow$ suriable puatitic

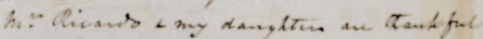

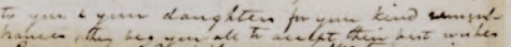

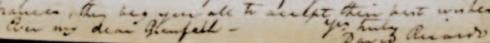

Figure 1 Ricardo's letter (Ricardo 1823), folio 2 verso (left) and folio 1 recto (right)

additions could be made to the circulation the price of silver would probably seldom be above $5 / 2$, (unless there were to be a great fall in the relative value of gold), but as these additions can be made by the Bank of England's increasing the paper circulation, it is quite possible that if the new project be adopted the value of new money may fall in the proportion of $5 / 6$ to $4 / 11 \frac{1}{2}$, or 10 pc. ${ }^{\mathrm{t}}$.

I believe that we now possess the best system of currency that has ever been established in any country, \& I shall very much regret its being interfered with. It would under our present circumstances be wrong I think to make any alteration in our system even if it could be shewn to be one strictly accordant to sound principles, because after what has occurred all changes are apt to weaken our reliance on the fixedness of the currency, without which it must be $\mid$ in $\mid$ an unsatisfactory state: How much stronger is $[\mathbf{2} \mathbf{v}]$ this objection against the projected change, which is neither more nor less as Lord Grenville has justly stated it, but to do indirectly what Parliament, tho so much urged, has refused to do directly. - I shall be sorry if Huskisson lends himself to such 


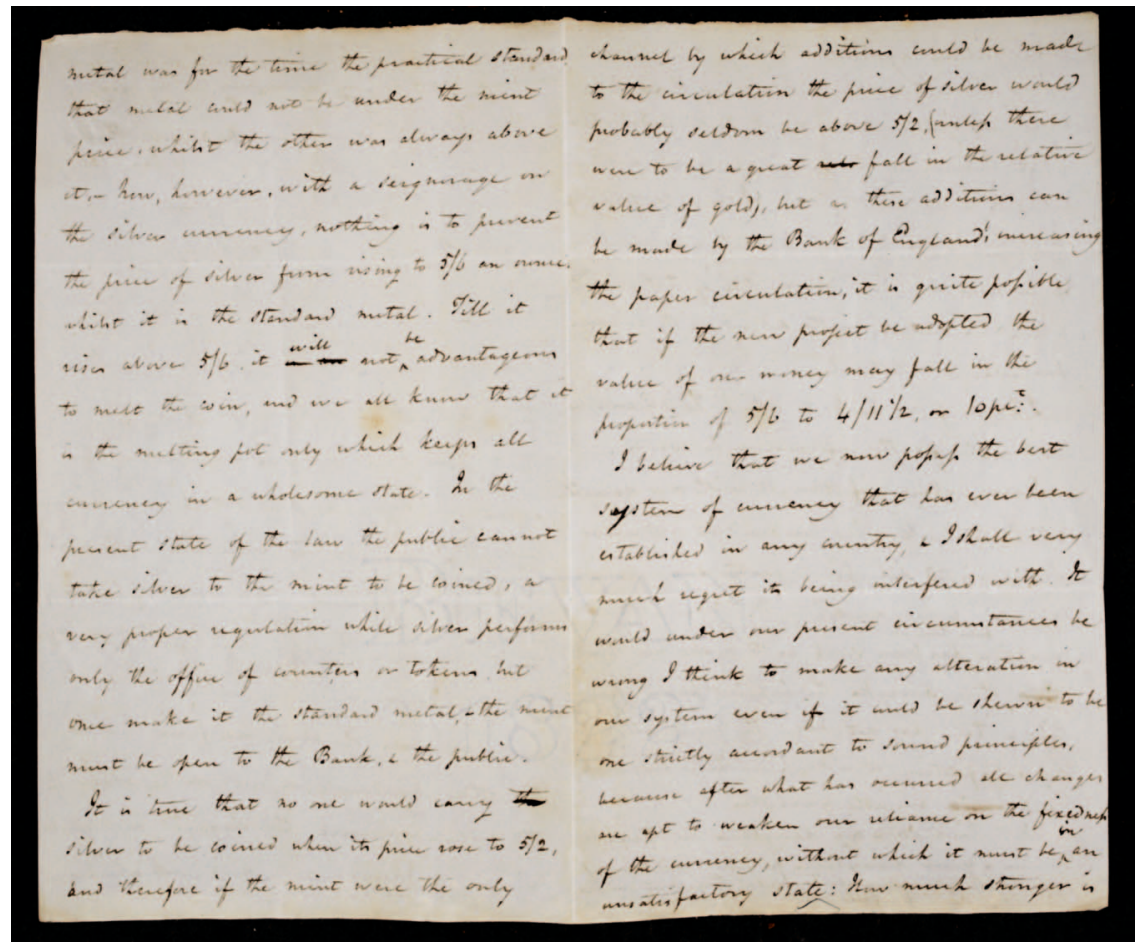

Figure 2 Ricardo's letter (Ricardo 1823), folio 1 verso (left) and folio 2 recto (right)

a scheme - if he does, he will lose a little of that respect which his conduct on the subject of the currency has hitherto entitled him to.

I know of no book to which Lord Grenville could refer for the information he wants.

I am passing a fortnight with my daughter $\mathrm{M}^{\mathrm{rs}}$. Clutterbuck \& her husband, at Widcomb. I have visited successively, for the same period, my son, \& my daughter, $\mathbf{M}^{\mathrm{rs}}$. Austin. My reception |from them all| has been such as to make me think these 6 weeks the happiest period of my life - there has not been the least alloy to my satisfaction at witnessing their happiness and merit [?] amiable qualities.

$\mathrm{M}^{\mathrm{rs}}$. Ricardo \& my daughters are thankful to you \& your daughters for your kind remembrance, they beg you all to accept their best wishes.

Ever my dear Grenfell -

$\mathrm{Y}^{\mathrm{rs}}$. truly

David Ricardo 
[1 $\mathbf{r}$ ] I shall be in London on the $1^{\text {st }}$ of feb. ${ }^{\text {ry }}$. I agree with you in your opinion of the situation of the country.

\section{The historical context of the letter}

\subsection{Ricardo on the currency at the time of the letter}

3.1.1 'The triumph of science and truth'. On 26 May 1819, after the convertibility of the Bank of England note had been suspended since 1797, the House of Commons adopted the nine resolutions embodied in the report of the secret committee on the resumption of cash payments. ${ }^{8}$ The Fourth to Seventh resolutions stated that:

the Bank shall be liable to deliver, on demand, Gold of standard fineness, having been assayed and stamped at His Majesty's mint, a quantity of not less than sixty ounces being required in exchange for such an amount of Notes of the Bank as shall be equal to the value of the Gold so required. (Ricardo 1951-1973, V: 7-8) ${ }^{9}$

A calendar was set in these four resolutions to implement a gradual return to note convertibility at decreasing rates; it started on 1 February 1820 to end up on 1 May 1821 at the pre-1797 rate of $£ 317$ s $101 / 2 \mathrm{~d}$ per ounce of standard gold. In spite of the Bank's objection that these resolutions 'would have the effect of fettering the Bank so as to cause an inconvenient reduction of the currency' (Ricardo V: 8), and although the Eighth resolution stated the return to convertibility into coin on 1 May 1823, this three-year implementation of the convertibility into bullion - with the prospect that, if it worked, it could be made permanent - was the triumph of DR.

He had suggested what would be known as the Ingot plan as early as 1811 in the appendix to the fourth edition of The High Price of Bullion, developed it in details in his Proposals for an Economical and Secure Currency (1816), and incorporated it in the second edition (1819) of On the Principles of Political Economy, and Taxation. Two days before the vote in the House of Commons, DR, who was a Member of Parliament for Portarlington, had delivered a speech whose transcript by Hansard ended so: 'The hon. Member sat down amidst loud and general cheering from all sides of the House' (Ricardo V:

8 For the story of the legislative process leading to that resumption, and the role of DR in it, see Sraffa (1952b).

9 From now on, when references are to the Sraffa edition of The Works and Correspondence of David Ricardo (Ricardo 1951-1973), we will only mention the volume and the pagination. 
17). In a footnote, Sraffa quotes Mallet's diary saying that 'The phenomena of that night was Ricardo' and reporting that in a private party a few days afterwards, the Duke of Wellington had 'remained in conversation with him [DR] for 20 minutes' (Ricardo V: 17 n. 2). After the legislative process had been completed and the law proclaimed (on 2 July 1819), DR could describe it in a letter to Trower dated 8 July 1819 as 'the triumph of science and truth in the great councils of the Nation' (Ricardo VIII: 44).

Why was DR's Ingot plan so important in his own eyes? Although the logic of the plan was not recognised at the time, ${ }^{10}$ convertibility into bullion implied two consequences. On the one hand, it aimed at eliminating metallic circulation, since the paper money was no longer convertible in another currency (the gold coin), but in the non-circulating standard only. By de-monetising gold in domestic circulation (gold remained the standard of money, but was no longer money), the Ingot plan excluded any internal drain of the Bank's reserves due to the alteration of the coins and increased consequently the security of the monetary system. On the other hand, convertibility into bullion being de facto restricted to export, the Bank's reserves could be lower than with convertibility into coin, all the more so since the regulation of the note issue by watching the market price of gold reduced the risk of external drain.

Unfortunately, 'the triumph of science and truth' did not last. During the 1819 legislative process, an amendment had been introduced according to which, starting on 1 May 1822, the Bank would have the choice to pay its notes in coin or bullion (Ricardo V: $8 \mathrm{n} .1$ ); knowing the hostility of the Bank to bullion convertibility, this implied to shorten the Ingot plan experiment by one year. When the date of the return to pre-war parity (1 May 1821) came, a new act decided to anticipate this possibility of choice. Finally, DR's plan was legal only from 1 February 1820 until 1 May 1821; this was only formal, since during that period the market price of gold was below the legal price, so that only 13 'Ricardoes' (the popular name for the stamped ingots) were demanded as collectors' pieces out of the 2028 delivered in 1820 by the Mint to the Bank (Sraffa 1952b: 368-70).

3.1.2 Ricardo 'put upon his trial'. In spite of his plan having been dropped, DR was accused of being responsible for the deflation that followed the resumption of cash payments. In a controversy with Charles

10 On the tergiversations of Parliament about DR's plan, see Sraffa (1952b). The main objection to it was that, aiming at eliminating the circulation of gold coins, it implied the issuance of low-denomination notes. The problem of forgery was frequently put forward, but the reluctance of the Bank of England to enlarge the circulation of notes beyond the circle of traders also played a role. 
Western that covered two Parliamentary sessions (it started on 12 June 1822 and ended up on 11 June 1823; the hitherto unpublished letter was written just between these two sessions), DR maintained that the resumption of cash payments could only explain an increase in the value of money up to $10 \%$; one half as a consequence of the return to the pre-1797 mint price of gold, the other half as a consequence of an increase in the world value of gold, provoked by the purchases of the Bank of England in the perspective of a return to convertibility into coin. In DR's view, his Ingot plan could not be held responsible for that outcome, since, by economising on the gold reserves of the Bank, convertibility into bullion, if adopted, would have avoided one-half of the deflation having a monetary origin. An extract of the speech he delivered on 12 June 1822 expresses his irritation:

He [DR] hoped the House would pardon this personal reference to his own opinion: he was very averse from intruding on their patience; but he was as it were put upon his trial - his plan had not been adopted, and yet to it was referred the consequences which were distinct from it; and he was held responsible for the plan that had been adopted, which was not his, but was essentially different from it. (Ricardo V: 206)

There was more: DR was convinced that his plan had been torpedoed by the Bank of England, who, from the very beginning, had opposed it. As is well known, a Plan for a National Bank was found in his papers after his death on 11 September 1823, which developed an idea already present in Principles (Ricardo I: 361-3): the transfer of the note issue from the Bank of England to a public bank. ${ }^{11}$

It may therefore be surprising that, in such a state of mind, DR could say in the present letter, written amidst these stressing events:

I believe that we now possess the best system of currency that has ever been established in any country, E I shall very much regret its being interfered with. It would under our present circumstances be wrong I think to make any alteration in our system even if it could be shewn to be one strictly accordant to sound principles, because after what has occurred all changes are apt to weaken our reliance on the fixedness of the currency, without which it must be in an unsatisfactory state. ${ }^{12}$

DR's satisfaction only concerned the standard adopted for the monetary system - namely the adoption of gold as the only standard of the currency,

11 For an analysis of the controversy between Western and DR and a comparison between the Ingot plan and the Plan for a National Bank, see Deleplace (2008).

12 To facilitate the reading of our commentary, all excerpts of the letter published above are printed in italics. 
leaving to silver a secondary role. In spite of the bad fate of his Ingot plan, DR was then, on that question of the standard, in the same spirit as the one expressed in his above-mentioned speech of 24 May 1819:

He thought it right here to pay the tribute of his approbation to the late excellent regulations of the Mint. He entirely approved of making gold the standard, and of keeping silver as a token currency. It appeared to him to be a solid improvement in the system of our coinage. (Ricardo V: 16)

But this did not mean that he was satisfied with the system of note issuance, which left an entire liberty to the Bank of England of expanding or contracting its issues at will. As we will see below, this point was crucial for the argument developed in the present letter.

\subsection{Dramatis personae}

Several persons are mentioned in or connected with DR's letter. Some of them belong to his family. Others are beside him authors of the crossed correspondence mentioned in Section 1. A last one, although he remained backstage, was at the origin of the double standard project which motivated that correspondence. It is necessary to say a few words on each group, in order to situate DR's letter in that immediate background.

\subsubsection{Returning from a tour and visiting family. On 8 December 1822, DR} ended his tour on the continent and reached London from Dover. He spent a few days at his home of Brook Street in London and visited his son Osman and his daughter-in-law Harriett in Bromesberrow Place, Ledbury, from 12 to 27 December. He then left Bromesberrow for his estate of Gatcomb Park where he stayed for five days. On 1 January he visited the widow of one of his very good friends Thomas Smith of Easton Grey who had died on 31 May 1822. Then he spent two nights on his way to Bradley Wottonunderedge, which he reached on 3 January. There he visited, until 17 January, his daughter Mrs Austin (Priscilla usually called Sylla) and her husband. He left for Witcomb, Bath, where lived his older daughter Henrietta (or Netty) and her husband Thomas Clutterbuck whose father, Daniel Clutterbuck, had mediated when DR bought Gatcomb Park (Ricardo IX: 233, 234, 240-2, 250-1, 262-4 and 270). It is at Witcomb that DR wrote the letter dated 19 January 1823 to Grenfell that is now for the first time published.

3.2.2 Ricardo's links with Grenfell and Lord Grenville. Pascoe Grenfell (1761 to 1838) was one of the main speakers on monetary and financial subjects in the House of Commons and a watchful observer of the Bank of 
England's activities. He was member of the Bullion Committee in $1810^{13}$ and it was at his suggestion that DR undertook, in 1815, to write his Proposals for an Economical and Secure Currency (1816). It is probably through Grenfell that DR got acquainted with William Wyndham Grenville, Baron Grenville (1759 to 1834). Lord Grenville had been Prime Minister from 11 February 1806 to 31 March 1807. He formed a Coalition Government known as 'the Ministry of All the Talents' after which he did not take much leading part in the affairs of the State. He nevertheless remained Auditor of the Exchequer until his death in 1834.

As shown by his correspondence with his friend Hutches Trower, DR got acquainted with Grenville in 1818, a few months after the publication of the Principles (1817). Indeed, on 12 September 1817, DR wrote to Trower: 'I hear from Mr. Grenfell that Lord Grenville has written to him that he also is not reading but is studying my book; I should like to have such a Lord amongst my disciples' (Ricardo VII: 189; see also DR's letter of 27 August 1817 to Grenfell in Heertje 1991: 520). On 10 December 1817, DR announced to Trower that he had been acquainted with Lord Grenville's opinion on the Principles, 'which is favourable beyond my expectations. When I go to London I am, at his Lordship's desire, to be introduced to him. For Lord Grenville's judgement on matters of Political Economy I have always had the highest respect' (Ricardo VII: 220). This meeting took place in the beginning of 1818 (probably in March $^{14}$ ). Finally, DR's expectation to have Lord Grenville among his disciples seems to have been fulfilled for, on 11 January 1820, Lord Grenville called DR his 'master in this science [of political economy]' (Ricardo VIII: 151).

DR, Grenfell and Grenville had cooperated during the 1819 enquiry of the secret committees appointed 'to consider the State of the Bank of England, with reference to the Expediency of the Resumption of Cash Payments'. The Commons Committee included, among others, Grenfell, George Canning and William Huskisson, who were also members of the 1810 Bullion Committee, Thomas Frankland Lewis who took the lead in the examinations, Nicholas Vansittart (Chancellor of the Exchequer), George

13 According to Heertje, 'it is probable that Grenfell and Ricardo met during the time of the Bullion Report around 1810' (Heertje 1991: 519).

14 On 22 March 1818, DR summed up that meeting with Lord Grenville to Trower in the following manner: 'In an interview which I lately had with Lord Grenville I received from him the most flattering testimony of his favourable opinion of my endeavours to throw additional light on the science of Political Economy. Praise from Lord Grenville on this subject is particularly gratifying to me, because he has given many proofs of his persevering attention to it, and on all great discussions, of the correctness of his opinions' (Ricardo VII: 259). 
Tierney, Sir James Mackintosh and Robert Peel as chairman. In the Lord Committee the lead was taken by Lord Grenville and the Earl of Liverpool. The Committee also included the Earl of Harrowby (Lord President), the Duke of Wellington, the Marquis of Lansdowne, Lord King, Lord Lauderdale. ${ }^{15}$ The Committees took evidence from 24 witnesses between 8 February and 1 May, and DR was heard by both Committees. According to the entry in Mallet's Diary for 13 February 1819:

The Secret Committees of both Houses respecting the Restriction Act, also became a subject of interesting conversation. Mr. Ricardo is more at home here than in the maze of political reform. He had been closeted in the morning with Lord Grenville and Mr Grenfell; discussing various parts of that important subject. (Ricardo V: 352)

3.2.3 A central actor in the double standard project: Alexander Baring. DR's plan of convertibility into bullion had been supported before the Secret Committees by two witnesses. The first was Swinton Colthurst Holland, a partner with Baring Brothers, \& Co. who was heard before the Commons' Committee on 2 March 1819. The next day, this was Alexander Baring (1774 to 1848), one of the most powerful financiers in Europe, ${ }^{16}$ who expressed before the Lords' Committee 'a very favourable Opinion of the Plan of Currency suggested by Mr. Ricardo, as combining the Two Desiderata of an extensive Paper Circulation, with Security against its Depreciation' (House of Lords 1819: 107). Baring was favourable to a return to parity at the old mint price of $£ 317 \mathrm{~s} 101 / 2 \mathrm{~d}$ an ounce of standard gold and considered convertibility into bullion one of the best measures to avoid internal drains and to preserve the country from a sudden reduction of paper.

Nevertheless, contrary to DR, Baring advocated a double standard (gold and silver) rather than a gold-standard system. When asked before the Commons' Committee on 12 March 1819:

15 See Mallet (in Ricardo V: 352-4), who commented: 'There cannot be a better Committee than in the Lords. The Committee of the Commons is not so good. Huskisson is the only man who understands the subject thoroughly [...] $\mathrm{Mr}$ Grenfell is able and well acquainted with the subject; but not of the calibre of Lord Grenville' (V: 354).

16 Between 1817 and 1819, Baring negotiated bond issues on behalf of the French Government to fund French reparations payments. As the Duke of Wellington wrote to the Earl of Liverpool in 1818: 'The fact is, that Baring having the French finances in his hands, and French loans being in fashion in England, has to a certain degree the command of the money market of the world' (Wellington 1858-1872, XII: 249). 
When you state that great facility would arise from the payments of the bank being made indifferently in either of the two precious metals, silver or gold, do you apply that observation only to the supposition of the system of bullion payments being adopted, or equally to a resumption of cash payments in the ancient manner [in coins]?

Baring unambiguously answered: 'I should prefer the mixed standard under either circumstances' (House of Commons 1819: 283). According to Baring:

great Advantages would result to Commerce, and great general Facility in procuring a sufficient Abundance of the precious Metals, by not excluding either, and more especially not that Metal which forms the Standard of Value in almost every other Part of the World [Silver]. (House of Lords 1819: 132)

However, Baring's suggestion of a double standard had no echo in the final reports of the Committees (6 and 7 May), which led on 26 May to the adoption of a set of resolutions by the House of Commons. As seen above, these resolutions planned a progressive return to note convertibility into gold at a decreasing rate and the adoption of DR's plan as a temporary measure from 1 February 1820 until 1 May 1823.

The general deflation and the severe agricultural distress witnessed in Great Britain, from early 1819 until late 1822, brought a serious challenge to the project of returning to the gold parity of $£ 317 \mathrm{~s} 101 / 2 \mathrm{~d}$ an ounce. On 8 May 1820 a petition of the merchants of London on the distressed state of the country was presented by Baring, who showed the first signs of a change of mind on the causes of the distress. In 1819, he had declared before the Lords' Committee that the distress was unconnected with 'the State of the Currency or the Operations of the Bank', and 'ha[d] its Origin in One of those Fluctuations in Commerce, which every Five or Six Years usually occur. Its immediate Cause [was] the great Decline of the Prices of some of the principal Articles of Trade', and this decline was 'a Fall from the old War to the present Peace Prices' (House of Lords 1819: 133-4; see also House of Commons 1819: 274). In May 1820, Baring modified his views and 'felt that the change in the currency was one of the circumstances that weighed on the country' (Hansard 1820-1830, series 2, I: 195). And again, during the debates on a petition of the citizens of Birmingham on 8 February 1821: 'A very considerable part of the distress, he was convinced, arose from the nature of the currency' (Hansard 1820-1830, series 2, IV: 532). He then asked for a committee to investigate the question and suggested:

the expediency of giving to the Bank the option of paying either in gold or silver, that the value of the two precious metals might be rendered more equal, and the present pound sterling, which was somewhat too high, relaxed. He wished to relax a cord 
which was at present stretched somewhat too tightly. (Hansard 1820-1830, series 2, IV: 535$)^{17}$

In spite of Baring's renewed support to his own scheme of bullion convertibility, DR (who had entered in Parliament in the early part of 1819) criticised Baring's suggestions on several occasions from May 1820 to April 1821 (Ricardo V: 46, 77-8, 91-6 and 105-7; see below). On 9 April 1821, Baring's proposition to appoint a Select Committee to reconsider the 1819 Resumption of Cash Payments was defeated 141 to 27.

3.2.4 A crossed correspondence opposing Baring's project of a double standard. The question of the double standard reappeared in DR's correspondence in 1823, in a letter to Trower written on 30 January:

\begin{abstract}
There has been a talk, I believe nothing more, amongst ministers about restoring the two standards, but I am assured all thoughts of it are relinquished.-Lord Liverpool is very decidedly against it. I am sorry to hear that Huskisson is not much disinclined to it. I have lately seen a letter from Lord Grenville on this subject to one of his friends [Grenfell], in which he expresses himself strongly and ably in favor of the single standard. His Lordship's opinions on the subject of the currency appear to me to be very sound. Lord Lansdowne I have been informed is inclined to the two standards Baring I suspect is the ringleader in this conspiracy. (Ricardo IX: 270)
\end{abstract}

As mentioned above in Section 1, important unpublished materials, including letters of DR, Grenfell and Grenville, relating to this period, are to be found in the second series of the Dropmore Papers of Lord Grenville deposited at the British Library. This crossed correspondence enlightens the episode DR alluded to in his letter to Trower. On 10 January 1823, Grenfell wrote to Grenville (Grenfell 1823a) that upon the suggestion of Huskisson (1770 to 1830$),{ }^{18}$ who acted in concert with Baring, the government was 'seriously considering [...] of altering the Standard-by making Silver, as well as Gold, legal tender' and thus restoring bimetallism. Lord Grenville answered to Grenfell in a long letter on 12 January (Grenville 1823) ${ }^{19}$ that:

17 After Baring's speech DR wrote to Trower on 2 March 1821: 'The subject of the two standards will again come under discussion, and I shall be prepared to shew from Baring's evidence that there are insuperable objections to the alteration which he proposes. He, I am sure, ascribes too much to the rise in the value of money' (Ricardo VIII: 349-50).

18 William Huskisson was Member of Parliament and from 1823 to 1827 President of the Board of Trade and Treasurer of the Navy.

19 Since the watermark is 'J GREEN \& SON' with the vintage ' 1824 ', this document is a later copy kept by Grenville of the minute of the letter he sent to Grenfell. All the letters from Grenfell mentioned are original. 
With all Baring's abilities and knowledge, he made not the least impression on my mind, when [in 1819] he stated to us at the House of Lord's committee the great convenience and advantage of a mixed standard, fluctuating with the variable relations between silver and gold.

According to Grenville who restated DR's 1819 argument, the cost of production of gold was less subject to rapid changes than that of silver. Thus, gold approached nearest to that quality of 'perfect fixedness' (Grenville's emphasis) that would be required by a standard. Lord Grenville also shared DR's opinion on the double standard, arguing that 'a standard composed of two metals, either of which may be resorted to at the option of the payer, is necessarily one of perpetual mutability'. Moreover, according to Lord Grenville, what was actually intended by Baring and Huskisson was not only to re-introduce silver as standard, but 'to do indirectly, and to a small extent, what parliament tho' so much urged, has refused to do directly, and to a large extent - viz to lower the standard.'

Although he 'had not heard that any such thing was seriously in the contemplation of Government', Lord Grenville considered it a real threat:

on the one hand Country Gentlemen, and Country Peers, both in Scotland and in England, should be very apt to catch at any thing which in their present difficulties is held out to them as offering the chance of relief - or on the other hand that Government should be most anxious to conciliate by any practical concession, (even if it be in part a departure from the true principles of political economy,) so large a body of upright and well intentioned men, and real well wishers to our establishments, at a moment when they are assailed on every side.

To those considerations on the question of restoring bimetallism, Lord Grenville added a 'particular inquiry' to Grenfell:

A question has presented itself to me in the course of my reading, for the elucidation of which it is necessary to ascertain what has been at different periods, remote, intermediate, and recent, the relative market price of silver and copper. Their present relation you could tell me in a moment, and even of that I am ignorant - but you could perhaps direct me to some book where I could find the same information for more distant periods.

Grenfell, after receiving Grenville's letter, communicated it to DR, ${ }^{20}$ who, in the letter we now publish, dated 19 January, commented Grenville's opinion on the question of restoring the two standards and

20 Grenfell's letter to DR is wanting. 
gave his own arguments for opposing such a project. On 21 January, Grenfell wrote to Grenville (Grenfell 1823b) to give him DR's opinion. Grenfell quoted the first two sentences of DR's letter and added that he had not 'done wrong' by communicating Grenville's letter to DR for 'it may not be displeasing' to Grenville to see that DR shared his opinion on the currency question. Grenfell indicated that DR knew no book that contained the information Grenville was looking for on the prices of silver and copper. On 23 January, Grenfell addressed another letter to Grenville (Grenfell 1823c). The content of this last letter explains why DR's letter is today in Grenville's papers: ${ }^{21}$ Grenfell mentioned that he enclosed in his mail the letter of DR: '[ I am] thinking your lordship may not be averse to see what he [DR] says upon the subject of the prepared - or rather, (I hope) conjectured alteration of the standard'. This letter from Grenfell finally gives an interesting piece of information on what DR had in mind when he wrote at the end of his own letter that he agreed with Grenfell's 'opinion of the situation of the country': 'Ricardo postscript refers to an opinion which I expressed to him, as to Prosperity of the country, notwithstanding the pressure upon the agricultural [undeciphered]'.

The crossed correspondence between DR, Grenfell and Grenville confirms that, in January 1823, Baring had the support of Huskisson in his project of establishing a double standard. However, this project did not lead to any parliamentary move in 1823 and was let aside for some years. In 1826 and 1828 Baring and Huskisson attempted to get the support of the Duke of Wellington to restore a double standard system at the old gold

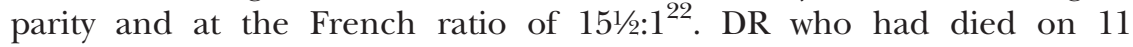
September 1823 was no longer in Parliament to answer their project. However, 'the outcome of this discussion was nil, and [...] neither Baring nor any other Government spokesman made any moves in Parliament on behalf of silver' (Fetter 1965: 126).

\section{The analytical content of the letter}

\subsection{Four elements involved}

The letter deals with the question of the double standard, as it would operate if silver was re-introduced as legal standard side by side with

21 It also explains why DR's letter is wrongly catalogued as a letter to Grenville, although it was sent to Grenfell.

22 Huskisson's Memorandum is reproduced in Wellington (1867-1880, 3: 98-104). 
gold. ${ }^{23}$ The understanding of that question implies to disentangle four elements:

- The legal double standard, as opposed to a single one.

- The seignorage on the silver coin, as opposed to free coinage.

- The free access to the minting of silver, as opposed to its prohibition. ${ }^{24}$

- The mixed circulation of notes and coins, as opposed to a pure metallic circulation.

At the time (1823) when DR wrote the letter, the situation combined these elements in the following way: there was a single standard (gold); the silver token coin bore a seignorage of $4 \mathrm{~d}$ per ounce (its current legal value was 5 s $6 \mathrm{~d}$ per standard ounce, while its mint price was 5 s $2 \mathrm{~d}$ : a $6.45 \%$ seignorage was then charged on the silver coinage); neither the public nor the Bank had access to the mint for silver coining (but the government only); there was a mixed circulation of full legal-tender gold coins, restricted legal-tender (up to 40s) silver coins, and Bank of England convertible (in gold coins) notes, deprived of legal tender. The case examined (and opposed) by DR combined the re-introduction of a legal double standard (as before 1797), which would imply for silver free access to the mint and full legal tender, the two other elements (seignorage on the silver coin and mixed circulation) being left unchanged. To put it briefly, DR examined the case where the only change in the British monetary system would be the re-introduction of a double standard (with its consequences for legal tender and access to the mint), the other aspects being left unchanged, including the seignorage on the silver coin introduced in 1817. There was a good reason why DR did not consider the abolishment of the latter: he was favourable to a slight seignorage on any coin, whether silver or gold. ${ }^{25}$ Although he did not refer explicitly to

23 This question should not be confused with the one of silver being eligible as the sole standard, instead of gold. On that issue, DR had first favoured silver, before changing his mind in favour of gold on a matter of fact: the introduction of machinery in silver (but not gold) mines, which made silver a more variable standard than gold (see Ricardo V: 390-1 and 427).

24 One should not confuse free access to silver coinage - which means that everyone may bring silver to the mint to be coined - and free silver coinage which means that the coinage is free of charge (no seignorage). The former does not imply the latter.

25 Ricardo wrote in the Principles: 'To a moderate seignorage on the coinage of money there cannot be much objection' (I: 371). During an evidence before the secret committee on resumption on 4 March 1819, DR had favoured the possibility to obtain immediately the gold coin for bullion at the mint (Ricardo V: 380 and 387 ), instead of the delay then imposed, which, because of the loss of 
that position in the present letter, he considered that the seignorage on the silver coin was an improvement in the British monetary system, and there was no reason to renounce it for the benefit of a return to a legal double standard.

The argument of DR in the letter is twofold: not only the reintroduction of a double standard would produce the same 'inconveniences' as it did 'formerly' when it operated - namely 'changing from one [standard] to the other' in the course of time - but the present conditions would introduce an additional damage: 'the value of the new money may fall [...] [by] $10 p c^{t}$.' The first argument had been developed numerous times by DR during more than ten years, and repeated during the debates on resumption in 1819; one may understand that he did not feel necessary to devote more than one sentence to it, all the more so since, as he stressed in 1817 in the Principles, this 'had been unanswerably demonstrated by Mr. Locke, and had been noticed by all writers on the subject of money since his day' (Ricardo I: 369; the same attitude appears in The High Price of Bullion of 1810, see III: 65). By contrast, the second argument - to which DR devoted more than one-third of the letter - was entirely new. Of course, the possibility of a fall in the value of money was here explained by DR thanks to arguments used frequently by him in his monetary analysis; they cannot therefore be considered as new. However, what cannot be found elsewhere in his writings, in print, speech, manuscript form or correspondence, is that use in the discussion of the

interest, implied what 'may strictly be called a small seignorage' (V: 402). In an unusual manner, DR asked to be again examined on 19 March and, probably to be correctly understood, he delivered a written paper. He stood to his former answer 'as far as regards our circulation' (Ricardo V: 401), but he wanted 'to amend' it by stressing an inconvenience linked to the absence of seignorage: 'a great inducement offered to all exporters of gold, to exchange their bullion for coin previously to its exportation' (Ricardo V: 401), since the advantages of the coins (certified fineness, divisibility) would no longer be compensated by the cost of obtaining them. DR's proposal was the following: 'If it be decided, that under all circumstances, a currency, partly made up of gold coin, is desirable, the most perfect footing on which it could be put, would be to charge a moderate seignorage on the gold coin, giving at the same time the privilege to the holder of bank notes, to demand of the bank, either gold coin or gold bullion at the mint price, as he should think best' (V: 402; this was the proposal made in Principles; see Ricardo I: 372 and also V: 429 and 431). However, even 'moderate', a seignorage on a coin 'has also its inconveniences' (Ricardo V: 402) - as we will see below. DR's conclusion was straightforward: 'I am still of opinion, that we should have all its advantages [of a seignorage], with the additional one of economy, by adopting the plan, which I had the honour of laying before the Committee when I was last before them' (Ricardo V: 403) - namely, the Ingot plan. 
double standard. This is the reason why the discovery of the present letter is so important.

We will first recall the general argument about the change in the standard, and will then concentrate on the new argument about the fall in the value of money. Although it was new, DR could compress it in a little more than one page, since the letter was addressed to someone well acquainted with these matters. It is nevertheless complex and requires some careful examination, especially since the question of the double standard - and even of a single one - is no longer familiar.

\subsection{The general argument against the alternating standard}

Thirteen years before, in The High Price of Bullion, DR had already opposed the double standard, on the ground of the unavoidable change in the effective standard that it would entail: 'No permanent* ${ }^{26}$ measure of value can be said to exist in any nation while the circulating medium consists of two metals, because they are constantly subject to vary in value with respect to each other' (Ricardo III: 65). It was so because the market ratio of the price of gold to that of silver was subject to changes due to the respective conditions of production of the two metals, as for every commodity, whereas the relative value of gold and silver in the coins was legally fixed. Whenever the market ratio fell below the legal ratio, no one would bring silver to the mint to be coined, because it was more advantageous to sell it in the market for gold coins; gold became the 'practical standard' (as it is labelled in the present letter). The opposite occurred when the market ratio rose above the legal ratio:

Not only would not gold be carried to the mint to be coined, but the illicit trader would melt the gold coin, and sell it as bullion for more than its nominal value in the silver coin. Thus then gold would disappear from circulation, and silver coin become the standard measure of value. (Ricardo III: 68)

26 The asterisk refers to a footnote by DR which begins so: 'Strictly speaking, there can be no permanent measure of value. A measure of value should itself be invariable; but this is not the case with either gold or silver, they being subject to fluctuations as well as other commodities' (Ricardo III: 65). As is well known, DR had in mind the theoretical problem of the invariable measure of value, which would upset him until the end of his life. In the practical choice of the monetary standard, however, one could satisfy oneself with the commodity the least variable in value, although that criterion itself raised logical difficulties (see for example in a speech dated 12 June 1822; Ricardo V: 211). 
Examined by a Lords committee on 24 March 1819, DR had produced figures, extracted from Mushet's Tables, showing that in the 1770s and 1780 s the market ratio had varied up to $15 \%$ in the space of two or three years, and he had concluded: 'The greatest Inconvenience would result in raising or lowering suddenly the Value of the Currency to so great an Extent' (Ricardo V: 427).

Therefore, although it was legally proclaimed, there could never be practically a double standard, except by chance when the market ratio happened to coincide with the legal ratio. One corollary was that, in such a monetary system, only one metal at a time could have a market price above its mint price. For example, if the market ratio was below the legal one, gold was the standard and consequently at or below its mint price, while silver was above it. We will see below that the letter recalls this observation, which had been already made by DR in The High Price of Bullion. ${ }^{27}$

According to DR, this situation of a legal double standard working practically as an alternate single one operated until $1797 .{ }^{28}$ Although the relative value of gold in silver was such that gold was de facto the standard, an increase in this relative value could have promoted silver as the sole standard, and this possibility of change in the standard was enough for DR to reject the legal double standard. One should observe that, according to DR, silver could have become the standard, in spite of the fact that it was legal tender only up to $£ 25$. As explained in the Principles:

[Before 1797] gold was in practice the real standard of currency. That it was so, is no where denied; but it has been contended, that it was made so by the law, which declared that silver should not be a legal tender for any debt exceeding $25 \mathrm{l}$., unless by weight, according to the Mint standard. But this law did not prevent any debtor from paying his debt, however large its amount, in silver currency fresh from the Mint; that the debtor did not pay in this metal, was not a matter of chance, nor a matter of compulsion, but wholly the effect of choice; it did not suit him to take silver to the Mint, it did suit him to take gold thither. (Ricardo I: 368)

27 'An excess in the market above the mint price of gold or silver bullion, may, whilst the coins of both metals are legal tender, and there is no prohibition against the coinage of either metal, be caused by a variation in the relative value of those metals; but an excess of the market above the mint price proceeding from this cause will be at once perceived by its affecting only the price of one of the metals. Thus gold would be at or below, while silver was above, its mint price, or silver at or below its mint price, whilst gold was above' (Ricardo III: 77).

28 The legal double standard continued after 1797, but the suspension of cash payments of notes changed completely the working of the monetary system. As mentioned by DR in 1809, 'when the prices of both the metals are above the mint prices it is proof conclusive of bank notes being at a discount' (Ricardo III: 43) - a contrast with the pre-1797 situation, when the market price of only one metal could be above the mint price. 
In fact, silver was not prevented by its restricted legal tender from being the standard because this restriction only applied to the debased coin; since the law authorised to pay any amount 'by weight, according to the Mint standard', that meant that full-bodied silver coins ('fresh from the Mint') were full legal tender in the same way as were gold coins. Consequently, for silver becoming the standard, the important points were the legal possibility of paying by standard weight and the free access to the mint to obtain new silver coins, not the restricted legal tender of debased coins. ${ }^{29}$

These two crucial provisions, which existed before 1797, disappeared in 1817. First 'it was enacted that gold only should be a legal tender for any sum exceeding forty shillings' (Ricardo I: 369); that is, silver was no longer legal tender above this sum, even by standard weight. Second, for contingent reasons (the market price of silver was then below the mint price of $5 \mathrm{~s} 2 \mathrm{~d}$, and the mint would have been flooded with silver bullion brought in for coinage), the royal proclamation implementing free access to the mint for silver was not issued (see Fetter 1965: 67). Both provisions reflected the secondary role devoted to silver in the monetary system: silver coins were de facto reduced to token currency. But if the double standard was to be reintroduced, silver currency had to be again put on the same footing as the gold one. It is the reason why, in the letter, DR insisted on the fact that, by contrast with what was the case at the time he wrote, free access to the mint for silver should again be granted:

In the present state of the law the public cannot take silver to the mint to be coined, a very proper regulation while silver performs only the office of counters or tokens, but once make it the standard metal, Eं the mint must be open to the Bank, Eं the public.

This re-introduction also implied the possibility of paying any sum in fullbodied silver coins be enacted again (unrestricted legal tender). It seems therefore that, if the legal double standard was to be re-introduced, the British monetary system would be put again in the state ruling before 1797 , with the same 'inconveniences' as 'formerly' - namely the practical possibility of a change of standard in the course of time. But the 'projected change' implied more than that.

\subsection{The specific argument of a prospective fall in the value of money}

After the Silver coinage act adopted by Parliament in 1816 and proclaimed in 1817 the legal double standard system would not work in the same way as

29 This is the reason why DR did not mention that restriction in the letter: it did not prevent the double standard from having legally existed before 1797 (see also Ricardo's 1811 Reply to Bosanquet in III: 177 and V: 106). 
the pre-1797 one did. Indeed it would retain from the latter those general 'inconveniences' of any double standard system, but it would add a specific difficulty: 'Since the new act for regulating the silver coinage, the execution of the plan will not be found so easy as the friends to it suppose'. The essential difference was summed-up by DR in the following way:

Formerly [...] whichever metal was for the time the practical standard that metal could not be under the mint price, whilst the other was always above it. Now, however, with a seignorage on the silver currency, nothing is to prevent the price of silver from rising to 5/6 an ounce whilst it is the standard metal. (Emphasis added)

As seen above, in the pre-1797 legal double standard system (that is without seignorage), one metal only (whichever it was, gold or silver) could have a market price above its mint price: the one that was not the 'practical standard' at the time. This had no more monetary consequence than for any ordinary commodity, since the currency was then attached to the other metal, which was at its mint price. With seignorage, one metal could have a market price above its mint price and remain the practical standard; therefore this rise did have a monetary consequence: a fall in the value of money. In the present circumstances that metal was silver, because since 1817 the silver coin bore a seignorage. There laid, according to DR, the novelty of the 'new project' of legal double standard. Thus we have to raise the question: Why did the existence of a seignorage on the silver coin - which DR considered as a favourable provision in itself (see above) - add a new inconvenience - no less than a $10 \%$ fall in the value of the pound - to an already objectionable double standard system? In other words, with a seignorage on the silver coin, why might the market price of silver rise up to $5 \mathrm{~s} 6 \mathrm{~d}$, signalling a fall of $10 \%$ in the value of the pound, measured in that restored standard?

The answer is not straightforward. In his above-mentioned correspondence to Grenville, dated 23 January 1823 and enclosing DR's letter, Grenfell wrote:

\footnotetext{
Ricardo seems to me to assume, that if that alteration [the double standard] takes place, the Mint price of Silver will be at the present current value of the Tokens viz 66 - I take it for granted, however, that if we are to be implicated with this alteration, the Mint price - as standard will not exceed its old rate of 62. (Grenfell 1823c; emphasised by Grenfell )
}

Obviously, Grenfell did not understand DR's argument: it is the market price of silver - not its mint price - which DR assumes to rise up to 66 pence $(5 \mathrm{~s}$ $6 \mathrm{~d})$, that is the appropriate measure of the current value of the pound - not its legal one - expressed in that standard. 
But why such a rise? It is interesting to notice that, in his speech of 8 February 1821 when he already opposed Baring's double standard proposal, DR himself had mentioned 62 pence (5s 2d) as the market price of silver which would result from that proposal:

With respect to his hon. friend's [Baring] recommendation of a double tender, it was obvious, that if that recommendation were adopted, the Bank [of England], although it seldom saw its own interest, would be likely to realise a considerable sum by the purchase of silver at its present reduced price of $4 \mathrm{~s} .11 \mathrm{~d}$. an ounce. But as this purchase would serve to raise silver to the Mint price of $5 \mathrm{~s}$. $2 d$. and comparatively to advance the price of gold, the consequence of which would be to drive gold out of the country, this was, among other reasons, an argument with him for resisting his hon. friend's doctrine. (Ricardo V: 77-8)

Two years later, in the hitherto unpublished letter, DR mentions 5s $6 \mathrm{~d}-$ instead of $5 \mathrm{~s} 2 \mathrm{~d}$ - as the prospective market price of silver resulting from the introduction of a double standard. This new figure strengthened his argument against the proposal, since the corresponding fall in the value of the pound would be $10 \%$ instead of $5 \%$. How can we explain that change?

The answer is in the letter itself:

It is true that no one would carry silver to be coined when its price rose to 5/2, and therefore if the mint were the only channel by which additions could be made to the circulation the price of silver would probably seldom be above 5/2, (unless there were to be a great fall in the relative value of gold), but as these additions can be made by the Bank of England's increasing the paper circulation, it is quite possible that if the new project be adopted the value of new money may fall in the proportion of $5 / 6$ to $4 / 111 / 2$, or $10 \mathrm{pc}{ }^{t}$.

Let us present the argument in detail. Again one should look at this question from the point of view of interest. As long as the market price of an ounce of standard silver bullion was below $5 \mathrm{~s} 2 \mathrm{~d}$ (the mint price), it was in the interest of its owner to bring it to the mint to have it coined, rather than to sell it in the market. But this stopped when a rising market price of silver reached the mint price. In a system of pure metallic circulation ("if the mint were the only channel by which additions could be made to the circulation'), this would put a check on any additional amount of silver coins, and consequently, according to DR's doctrine linking the value of the currency to its quantity, would prevent any further increase in the market price of silver: 'the price of silver would probably seldom be above 5/2'. In this hypothetical case there was, however, a restriction: '(unless there were to be a great fall in the relative value of gold)'. It was the consequence of the general inconvenience of a double standard: a sharp decline in the relative value of gold in terms of silver would bring it below the ratio of their mint prices; silver would cease being a standard, gold alone playing that role, and, as seen above, the market price of silver could rise above its mint price. But silver being no 
longer a standard, this rise did not mean a depreciation of the currency: no such depreciation could therefore occur in a hypothetical pure metallic circulation. ${ }^{30}$

Now, what about the case of a mixed circulation of coins of both metals and of notes convertible in specie ('as these additions can be made by the Bank of England's increasing the paper circulation')? There the seignorage came into play: as long as the market price of an ounce of standard silver had not reached $5 \mathrm{~s} 6 \mathrm{~d}$ (the current legal value of the silver coin), the Bank of England could not lose in paying its notes in silver specie, as it was its interest to do so (like any debtor) whenever silver was the "practical standard'. As a consequence, the Bank could expand its issues (and would do it because issuing notes by discounting bills was its way of earning profit) until that expansion depreciated the currency and raised the market price of silver to $5 \mathrm{~s} 6 \mathrm{~d}$. And this would occur 'whilst it [silver] is the standard metal' by which the value of the currency was reckoned. At a time when silver was rated $4 \mathrm{~s} 11 \frac{1}{2} \mathrm{~d}$ in the market, ${ }^{31}$ this rise in price up to $5 \mathrm{~s} 6 \mathrm{~d}$ implied a fall in the value of the currency by 10\%: 'it is quite possible that if the new project be adopted the value of new money may fall in the proportion of 5/6 to 4/111/2, or 10 $p c{ }^{t}$.

Could the market price of silver rise higher than 5 s $6 \mathrm{~d}$ ? Nothing could prevent the Bank to increase further its issues. But it would be at its own expense: above that level, it was the interest of any arbitrageur to cash notes for silver coins at the Bank at $5 \mathrm{~s} 6 \mathrm{~d}$, to melt them down and to sell the bullion back to the Bank (obliged to buy it in order to replenish its cash reserves) at a higher market price. This losing business would soon lead the Bank to reduce its issues, and that prevented the market price from rising above 5s 6d: 'Till it rises above 5/6, it will not be advantageous to melt the coin, and we all know that it is the melting pot only which keeps all currency in a wholesome state.'

The novelty of the letter lies in that complex argument (so complex that his correspondent Grenfell did not catch it). In his 1821 speech against Baring's double standard proposal, DR had explained the rise in price up to $5 \mathrm{~s} 2 \mathrm{~d}$ by the arbitrage behaviour of the Bank of England: its purchases of silver for profit pushed the market price of that metal up to the mint price. Now in the letter DR explained the rise in price up to $5 \mathrm{~s} 6 \mathrm{~d}$ by the issuing

30 Unless the circulating coins were debased, without a corresponding limitation of the quantity of newly-issued coins. But this is not the point here: only full-bodied coins are considered.

31 According to The Course of Exchange, the market price of silver bullion was quoted continuously at this rate from 19 November 1822 until 7 January 1823, after which date it was quoted at 4s 111/4; see Boyer-Xambeu et al. (1995: 272-3). 
behaviour of the Bank of England: its increased note issue would push the market price of silver as standard up to the current legal value of silver as coin.

Such a pernicious influence of the Bank on the value of the currency, in relation to the existence of a seignorage on the silver coin, had already been mentioned by DR when he had been examined on 19 March 1819 by the committee on the resumption of cash payments. The double standard was not then the issue but the seignorage itself, and we have seen above that DR was favourable to it. He nevertheless mentioned that 'a coin with a seignorage has also its inconveniences' (Ricardo V: 402): it gave the opportunity to the Bank of England of changing the value of the currency, ${ }^{32}$ a recurrent complaint by him. ${ }^{33}$ In the present letter, DR was more specific: the combination of a bad monetary system (the double standard one), of a good provision (the seignorage on the silver coin), and of the power given to the Bank to increase at will the circulation, might lead to a fall in the value of the currency.

Nowhere in the hitherto published writings of DR does this argument show up in the discussion of the double standard. As seen above, DR had frequently mentioned the variability in the value of money due to the double standard as a consequence of a change in the relative value of gold to silver in the market, not of the issuing behaviour of the Bank of England. He did publicly mention that behaviour as a source of instability in his defence of the seignorage on the silver coin, not his critique of the double standard per se. He also mentioned publicly that the double standard would lead to a rise in the market price of silver in relation to an arbitrage behaviour of the Bank of England, not its issuing one. The novelty of the

32 'The bank have the undisputed power of increasing the quantity of currency, and thereby of diminishing its value to its intrinsic worth. If silver, for example, were now the standard of our currency, and therefore a legal tender to any amount, the bank might issue their paper till they raised the price of silver bullion to $5 \mathrm{~s} 6 \mathrm{~d}$ per ounce, (the current value of the silver coin) without inconvenience to themselves; they might then reduce their issues, till silver fell to $5 \mathrm{~s} 2 \mathrm{~d}$; and thus they might alternately raise and lower the price of silver, between the limits of $5 \mathrm{~s} 6 \mathrm{~d}$ and $5 \mathrm{~s} 2 \mathrm{~d}$ as often as to them it might appear expedient. If there were no seignorage on the silver coin, and it were immediately exchangeable for silver bullion on the demand of the holder of bullion, it is evident that the price of silver would not rise above, nor fall below $5 \mathrm{~s} 2 \mathrm{~d}$ the mint price' (Ricardo V: 402).

33 In Principles DR developed the same argument: 'It must, however, be remarked, that in a country where a paper currency is established, although the issuers of such paper should be liable to pay it in specie on the demand of the holder, still, both their notes and the coin might be depreciated to the full amount of the seignorage on that coin, which is alone the legal tender, before the check [melting], which limits the circulation of paper, would operate' (Ricardo I: 372). 
present letter is, in an argument on the variability of the value of money, to link the double standard, the seignorage on the silver coin, and the issuing behaviour of the Bank of England.

\subsection{The political implications of the letter}

When DR wrote the letter on 19 January 1823, he knew that, after ' 6 weeks [he thought] the happiest period of [his] life', the return to London would start a difficult time for him as Member of Parliament. In spite of his compassion to the distress of agriculture and trade, he expected to be again accused of being responsible for it. ${ }^{34}$ This state of mind sheds light on the conclusion of his analysis: 'the projected change [in favour of the double standard], which is neither more nor less as Lord Grenville has justly stated it, but to do indirectly what Parliament, tho so much urged, has refused to do directly'. As it is acknowledged by DR, the wording of that sentence was borrowed by him from Grenville's letter to Grenfell, who had communicated it to DR (see above Section 3). What had the Parliament 'refused to do'? By imposing the return to the pre-1797 price of $£ 317 \mathrm{~s} 101 / 2 \mathrm{~d}$ for an ounce of standard gold, the Parliament had refused in 1819 to devaluate the sterling. If DR's forecast was right, the 'projected change' would be nothing else but a disguised way of having the currency fall in value. ${ }^{35}$

For DR, such a change was not the right answer to the problems of the time: as witnessed by his interventions in Parliament in 1822/23 particularly against Western - he argued that the distress of the country had its origin neither in the existence of a gold standard nor in the level of the legal price of gold. As a consequence he could not accept an alleged remedy, which would have been the re-introduction of a double standard and the falling value of the currency.

34 The fact that DR was deeply hurt by the accusations made against him of being responsible for the deflation is not only proved by his defence in Parliament, as exemplified by his above-quoted speech of 12 June 1822. In the private correspondence with his son Osman, intended to be a journal of his tour on the Continent and containing mostly his observations as a tourist, one of the very few economic remarks reads as follows: 'I am sorry you can give me no better account of the farmers - theirs is a pitiable situation and for the present I see no relief for them but in the liberality of their landlords, who are themselves in a state of suffering and not very able to afford assistance to others. [... ] I expect to be the object of much personal attack next session [of Parliament] but I comfort myself with the reflection that truth will prevail at last, and justice will in the end be done to my motives and opinions' (letter sent from Paris on 23 November 1822 in Ricardo X: 349).

35 As noted above in Section 3, Baring had since 1819 changed his mind about the appropriateness of the return to the pre-1797 value of the pound. 
One could feel disappointed by the fact that the conclusion of Ricardo the economist is nothing else but an affirmation by Grenville the politician. The importance of this hitherto unpublished letter lies precisely in Ricardo's ability to demonstrate that the adoption of a double standard will necessarily lead to a definite fall in the value of money. And this he does in a compact form that may not be found elsewhere in his writings. This letter testifies again to the analytical powers possessed by its author, as well as to the permanence and the consistency of his views on monetary issues.

\section{Acknowledgements}

The authors thank the two anonymous referees whose useful advices have significantly improved the paper. They also thank the British Library for granting permission to reproduce the letter, and Justin Clegg for his help with the manuscripts.

\section{References}

\section{Manuscript sources}

Grenfell, P. (1823a). Letter to Grenville (autograph, signed and dated), 10 January. Dropmore Papers (Series I). Add. 58977, f. 173-4. London: British Library.

Grenfell, P. (1823b). Letter to Grenville (autograph, signed and dated), 21 January. Dropmore Papers (Series II). Add. 69082, 6, f. 94-5. London: British Library.

Grenfell, P. (1823c). Letter to Grenville (autograph, signed and dated), 23 January. Dropmore Papers (Series II). Add. 69082, 6, n 98 . London: British Library.

Grenville, W. W., Lord. (1823). Letter to Grenfell (copy, dated), 12 January. Dropmore Papers (Series I). Add. 58977, f. 175-8. London: British Library.

Ricardo, D. (1823). Letter to Grenfell (autograph, signed and dated), 19 January. Dropmore Papers (Series II). Add. 69082, 6, n 102. London: British Library.

\section{Printed sources}

Boyer-Xambeu, M.T., Deleplace, G., and Gillard, L. (1995). Bimétallisme, taux de change et prix de l'or et de l'argent (1717-1873). Economies et sociétés, 29 (7-8): 5-377.

Deleplace, G. (2008). Les deux plans monétaires de Ricardo. Cahiers d'économie politique, 55: 13-33.

Fetter, F.W. (1965). Development of British Monetary Orthodoxy 1797-1875. Cambridge: Harvard University Press.

Hansard, T.C. (1820-1830). The Parliamentary Debates. Second Series. 25 vols. London: T.C. Hansard.

Heertje, A. (1991). Three unpublished letters by David Ricardo. History of Political Economy, 23: 519-26. 


\title{
Ghislain Deleplace, Christophe Depoortère and Nicolas Rieucau
}

Heertje, A. (2007). An unpublished letter by David Ricardo. History of Political Economy, 39: 545-50.

Heertje, A. and Weatherall, D. (1978). An unpublished letter of David Ricardo: To Thomas Smith of Easton Grey, 27 April 1819. The Economic Journal, 88: 569-71.

Heertje, A., Weatherall, D., and Polak, R.W. (1985). An unpublished letter of David Ricardo to Francis Finch, 24 February 1823. The Economic Journal, 95: 1091-2.

House of Commons (1819). Report from the Secret Committee on the Expediency of the Bank Resuming Cash Payments with the Minutes of Evidence. London: Charles Clement.

House of Lords (1819). Reports by the Lords Committees appointed a Secret Committee to inquire into the State of the Bank of England, with reference to the Expediency of the Resumption of Cash Payments; with Minutes of Evidence. In The Sessional Papers printed by order of The House of Lords (1844), Vol 18.

Ricardo, D. (1951-1973). The Works and Correspondence of David Ricardo, 11 vols. Edited by P. Sraffa, with the collaboration of M.H. Dobb. Cambridge: Cambridge University Press.

Shorter, A.H. (1957). Paper Mills and Paper Makers in England - 1495-1800. Hilversum: Papers Publications Society.

Sraffa, P. (1952a). Introductory notes to the correspondence. In Ricardo, D. (19511973). The Works and Correspondence of David Ricardo, Vol. VI. Edited by P. Sraffa, with the collaboration of M.H. Dobb. Cambridge: Cambridge University Press, pp. xiii-xli.

Sraffa, P. (1952b). Notes on the evidence on the resumption of cash payments. In Ricardo, D. (1951-1973). The Works and Correspondence of David Ricardo, Vol. V. Edited by P. Sraffa, with the collaboration of M.H. Dobb. Cambridge: Cambridge University Press, pp. 350-70.

Wellington, A.W., Duke of. (1858-1872). Supplementary Despatches, Correspondence, and Memoranda of Field Marshal Arthur, Duke of Wellington, 15 vols. London: John Murray.

Wellington, A.W., Duke of. (1867-1880). Despatches, Correspondence, and Memoranda of Field Marshal Arthur, Duke of Wellington, K. G. (in continuation of the former series). 8 vols. London: John Murray.

\begin{abstract}
This article transcripts and comments a hitherto unpublished letter by David Ricardo, dated 19 January 1823 and addressed to Grenfell. In this letter Ricardo opposes the adoption of a double standard of money, two years after the return to convertibility of banknotes and in the midst of an economic recession that pressed for drastic monetary changes. It contains an argument - linking the double standard of money, the seignorage on the silver coin, the behaviour of the Bank of England, and the fall in the value of the pound - which is to be found nowhere else in Ricardo's works.
\end{abstract}

\section{Keywords}

Ricardo, double standard, currency system 